of sunshine and altogether about 10 hours of daylight per day are required. As an example of the effect obtained by providing lighting for 10 hours each night with an illumination of about 4 foot candles, pansies after 83 days gave an average of approximately 16 flowers per plant as against 2 flowers for unlighted plants; and asters after 157 days' treatment bloomed 33 days earlier than usual. The redyellow rays accelerate growth by stimulating the chlorophyll and the absorption of carbonic acid. Electric cables are also described which are used for heating the soil, and excellent economical results have been obtained.

\section{Ancient Heating and Lighting Appliances}

ONE of the world's largest collections of heating and lighting appliances has recently been presented to the Smithsonian Institution together with an endow. ment for its maintenance. It begins from the fire drills with which primitive peoples started a flame by friction, and goes on to some of the latest appliances for lighting and heating. A description of the collection has been issued by the Smithsonian Institution. After the fire drill, the account passes to the percussion method, in which a hard stone, such as flint, gives a spark when struck against steel. The steel used was frequently made in an artistic form, and was called a 'briquet'. Some of these briquets dating from about A.D. 500 were unearthed in a farm in France in 1902. One specimen is inlaid with gold, and has bits of ruby-coloured glass embedded in it. There are also pistol-action lighters, which employ the principle of the flint and steel but simplify it by means of a trigger. This way of starting a fire came into general use about 1700 , and was developed from the flint-lock gun, the first of which appeared in England about 1626. Illustrating the period preceding matches, when light was obtained by chemical action, the collection contains a Döbereiner jar, introduced about 1823. Flame was produced by letting hydrogen come into contact with certain other substances. The lamps range from one about the size of a thumb to another as tall as a man. The latter was obtained from a Buddhist temple. Another curiosity is a rolling lamp which was used at Hindu weddings ; the light remains upright when the globe is rolled along the ground. There is also a horological lamp which tells the time of night by the amount of oil consumed.

\section{Anti-Vivisection Finance}

THE honorary treasurer of the Research Defence Society, Sir Leonard Rogers, in a recent issue of the Fight Against Disease (24, No. 1) directs attention to the sums spent on propaganda by anti-vivisection societies within recent years. Analysing the certified annual accounts from 1912 onwards, and making allowance on one side for missing reports, and upon the other for useful work for animals done by some societies, it is estimated that a sum of approximately $£ 600,000$ has been received for 'anti-vivisection' work, and nearly $£ 500,000$ expended. The success in raising funds, in spite of the verdicts of two Royal
Commissions against them, would appear to be partly due to a facile appeal to sentiment, aided by the lack of adequate medical and scientific knowledge of the masses to enable them to sift the 'anti-' statements. Anti-vivisection propaganda has sought to curtail the work of hospitals and veterinary colleges, and the one piece of useful work that might have been accomplished with the huge accumulated funds, the support of the 'Anti-Vivisection Hospital' at Battersea, has been allowed to lapse.

\section{Prevention of Disease in the Tropics}

A MeEting of the Industrial Advisory Committee of the Ross Institute (London School of Hygiene and Tropical Medicine) was held on April 16 under the chairmanship of Mr. G. H. Masefield, when reports were received upon the Institute's activities in India, Ceylon, and South, East, and West Africa. Malaria prevention has received much attention, and instances were given of the value of mosquito control in combating this disease. Other diseases, including yellow fever and the eye-fly pest of India and Ceylon, were also discussed. Allusion was made to the value of reinforced aluminium foil as a heat insulator; in a tea factory in Ceylon a reduction of temperature of $7^{\circ} \mathrm{F}$. at noon in the rolling room had been obtained by its use.

\section{British Medical Association: Annual Meeting}

THE one hundred and fourth annual meeting of the British Medical Association will be held in Oxford on July 17-25, under the presidency of Sir E. Farquhar Buzzard, regius professor of medicine in the University of Oxford. The meeting will be divided into the following sections under the presidents indicated: Medicine (Dr. A. G. Gibson); Surgery (Prof. G. E. Gask); Obstetrics and Gynæcology (Prof. H. Beckwith Whitehouse) ; Ophthalmology (Dr. P. E. H. Adams); Pathology and Bacteriology (Dr. E. W. Ainley Walker); Anatomy (Prof. W. E. Le Gros Clark) ; Diseases of Children (Dr. R. C. Jewesbury); Neurology and Psychological Medicine (T. S. Good); Orthopædics (G. R. Girdlestone); Oto-RhinoLaryngology (L. Golledge); Pharmacology and Therapeutics, with Anæsthetics (Prof. J. A. Gunn); Physical Medicine (Dr. W. J. Turrell); Physiology and Biochemistry (Prof. R. A. Peters); Radiology (R. H. Sankey); Tuberculosis (Dr. W. Stobie); Dermatology (Dr. S. E. Dore); History of Medicine (Dr. A. Chaplin); Medical Sociology (Sir George Newman); Nutrition (Dr. A. F. Hurst); Public Medicine (Dr. W. M. Willoughby). A popular lecture, entitled "Anthropology and Medicine", will be delivered on July 24 at 8 p.m. by Dr. R. R. Marett. In addition to the usual professional exhibitions, an exhibition of pictures illustrating the history of Oxford medicine will be open at the University Museum from July 20 until July 25. Further information can be obtained from the Secretary, B.M.A. Office, The Cottage, Keble Road, Oxford. 